Article

\title{
Playing for the Future: Using Codesign Games to Explore Alternative Sanitation Systems in London
}

\author{
Tse-Hui Teh \\ Bartlett School of Planning, University College London, London, WC1E 6BT, UK; E-Mail: t.teh@ucl.ac.uk
}

Submitted: 1 July 2019 | Accepted: 9 December 2019 | Published: 27 December 2019

\begin{abstract}
Public participation is viewed as a best practice in planning, and yet most people who participate in it (planners included) often feel that it is a cynical box-ticking exercise. Citizen participation rates are usually low, implying that they may feel this way too. There are two good reasons for this feeling: On the one hand, public consultation often only occurs when it is a mandatory exercise required by government for development approval; on the other, when public consultation occurs it is after much time and effort has been invested by professionals to develop a scheme therefore change is made reluctantly or not at all. These factors create a reactionary and adversarial atmosphere during consultation. These structural limitations mean that there is no time to find alignment of interests between project developers and the public, or to develop trust and collaborations. This article explores how codesign games as a form of public participation can be done at an early stage of project development to contribute to finding alignment of interests and collaborations between project developers and different public interests. The empirical case study is focussed on the possibilities for the retrofit of sustainable sanitation systems in London. Three future sanitation systems were developed by 14 workshop participants. They demonstrate new alignments of interests, from methods of collection and treatment, to new economies of reuse and production. It also established reasons why the current water-based sanitation systems are obdurate, and the work involved in keeping the status quo.
\end{abstract}

\section{Keywords}

actor-network theory; codesign games; coevolution; London; public participation; sanitation

\section{Issue}

This article is part of the issue "Towards Transformative Practice Frameworks: Planners, Professional Agency and Sustainable Urbanism" edited by Nezhapi-Dellé Odeleye (Anglia Ruskin University, UK) and Niamh Murtagh (University College London, UK).

(C) 2019 by the author; licensee Cogitatio (Lisbon, Portugal). This article is licensed under a Creative Commons Attribution 4.0 International License (CC BY).

\section{Introduction}

It is universally acknowledged that public participation is best planning practice. However, it is also universally acknowledged that most public participation events are cynical exercises in public relations and persuasion (Beebeejaun, 2016; Lowndes, Pratchett, \& Stoker, 2001). The idea of public participation in planning arose from the rejection in the 1960s of post-war planning and architectural projects from the 1940s and 1950s, (Brownill \& Inch, 2019). The projects of the 1940s and 1950s were inspired by a desire to improve housing stock by increasing access to sunlight, ventilation, open space and hygienic sanitation and bathing facilities (Le Corbusier, 1947;
Smithson, 1967). They were future-looking and took on the spare aesthetics of the modernists. By the 1970s, this sparseness no longer represented a future of glowing rationality in which everyone benefited from new scientific knowledge, instead it represented the inhumaneness of scientific rationality in which cars could take precedence over people, exemplified by the clash between Jane Jacobs and Robert Moses about Greenwich Village (Ballon \& Jackson, 2007; Caro, 2015; Jacobs, 1961). Jane Jacobs amongst other activists mobilised her neighbourhood to stand up and fight against the demolition of housing to make way for a highway. She noted the rich social interactions that occurred, supported by the three to five-storey mix of residential and retail uses comprising 
the urban fabric of Greenwich Village. Her public activism inspired planners to think about the necessity of consulting the public, before making sweeping changes to places that affect their lives. It was believed that seeking public opinion would enable more humane projects to be built. Sherry Arnstein (1969) gives the clearest framework to this belief, by grading different forms of public participation as rungs on a ladder. The lowest rung, manipulation, being the poorest form of public participation; and the highest, citizen control, being the best form of public participation.

In 2019, 50 years after Arnstein's categorisation, and over 50 years after ideas of public participation gained popularity, government policy embeds public consultation for large urban and infrastructural projects in many countries and is recommended by the United Nations (Brlík \& Pelčíková, 2018; Department of Economic and Social Affairs of the United Nations Secretariat, 2007; Drazkiewicz, Challies, \& Newig, 2015; European Council of Spatial Planners, 2016; Flores, 2005; Ministry of Housing Communities and Local Government, 2019; NSW Government, 2018). Plenty of creative ideas and innovations have been trialled (Brandt, Messeter, \& Binder, 2008; Lauwaert, 2009; Rumore, Schenk, \& Susskind, 2016; Sedlitzky \& Franz, 2019), yet we remain with a process that the public, planners and other built environment professionals regard as a box-ticking exercise for a foregone conclusion driven by technologyled solutions and returns on investment. This belief is not unfounded. Most proposals are submitted to the government for consideration after technical and financial feasibility studies have shown that profits will be reaped from the investment. Public consultation is used to demonstrate that projects raise little or no public outcry or objections. This defensive approach leaves no space for the exploration or discovery of collaboration and alignment of interests. It has built environment professionals guessing what an unknown public wantsand a public who feels powerless in the face of built environment professionals, who have a specialist skill set, knowledge, and time to gather salient evidence and think through convincing arguments as to why large urban infrastructural or building proposals could benefit the public.

These limitations are built into the structure of the development process that exist in most capitalist democracies (Drazkiewicz et al., 2015; Flores, 2005). Most proposers of change desire the shortest amount of time to have plans approved in order to keep costs and unknown future risks to a minimum. Governing authorities have a statutory amount of time to consider and determine the acceptability and planning policy compliance of a proposal. Consultants are time constrained by their agreed fee and profit margin. The public have little time to spare from already full lives to spend on planning processes they have little understanding of-or influence over. These processes typically force a reduction of public participation to a box-ticking exercise.
In these times of climate crisis (Intergovernmental Panel on Climate Change, 2018) valuable resources can only be expended to build new places of human habitation that attempt to address the wider needs of society and ecology. It is therefore necessary to pursue efforts to improve participatory methods to help build places that increase the welfare of people and ecologies. Codesign games are a participatory method that can engage all types of people and things in dynamic dialogues (Binder, Ehn, Michelis, Jacucci, \& Linde, 2011; Halse, 2010). It can involve people in forms of imaginative play, giving them a different context and thus freedom to find new ways to relate to the world and new forms of living.

This article first outlines seven problems with the use of Arnstein's ladder to frame public participation. It then explains how Collective Coevolution of Actant Trajectories (CCAT) structures the development of the participatory workshop format, content, and codesign games. After this there is an explanation of the workshop and codesign games that were used to explore alternative sanitation systems in London. The results of the final synthesis codesign game show how this format of participation opens up imaginative thinking and dialogue between people and things, demonstrating the benefits codesign games can bring to a participatory process.

\section{Problems of Arnstein's Participatory Ladder}

One of the most well-used models to frame public participation is Arnstein's ladder (Arnstein, 1969). Critiques of the ladder continue to inspire a plethora of ideas and research including collaborative planning, communicative planning, deliberative planning, coproduction of planning, public engagement, and participatory dialogues (Slotterback \& Lauria, 2019). The ladder expresses a hierarchical gradation of eight types of interaction between the public and institutions. At the base of the ladder is manipulation, and at the top is citizen control, passing through therapy, informing, consultation, placation, partnership, and delegated power on the way. It is generally viewed that the top of the ladder represents the best type of public participation because the citizenry controls the decision making process, whereas the bottom of the ladder is the poorest participation as it consists of manipulating public perceptions of projects. Arnstein's ladder, in advocating citizen control as the best form of public participation, divides society into technocrats and elites against all other people and assumes a lack of trust between these groups. The ladder does not acknowledge that public participation can be passive. Nonparticipation may be because citizens trust decision makers to have public interests at heart and feel no need to have input in the decision making process. While Arnstein's ladder continues to be a reference point for public participation today, it pitches the knowledge generated by different types of people in society against each other. This does not give rise to processes bringing different viewpoints together to make informed choices 
about the future, nor does it offer a way to incorporate nonhumans into the participatory frame.

The notion that citizen control is the best and most valid form of public participation is impractical in many life situations. The people most likely to participate are those who are most concerned about the issue at hand, who have time available to participate in the debate, have trust that the process will allow their view to have an effect and be taken into account, and have the skills to understand the often technical documentation and language used to communicate ideas. The members of the public able to fulfil all four criteria are necessarily few. People's lives are already full of concerns, busy with activities for work and personal pusuits (Schütz, Heidingsfelder, \& Schraudner, 2019). Trust may have been eroded by other interactions with the same institution, say by making suggestions for a different proposal which was never responded to (Schütz et al., 2019). And it takes approximately three to six years of undergraduate study, one to two years of postgraduate education, and two years of professional work experience before someone is a qualified built environment professional conversant in the technical language and communication tools (Royal Institute of British Architects, 2019; Royal Town Planning Institute, 2019).

A second problem with citizen control at the top of the ladder is that it presumes that the majority view has the best interests at heart for all members of the public. All types of people and majorities can all hold views that if upheld, damage environments and other groups of people (Hendrix, 2007). Regardless of socio-economic position, the majority may want to maintain the status quo because the effort, expense, and uncertainty of change are too great in comparison to anticipated benefit (Subašić, Reynolds, \& Turner, 2008). A simple transference of power from technocrats and elites to other citizens does not mitigate this circumstance. Exacerbating this is that sometimes change can have no tangible direct benefit to people whose effort is required, or whose life is disrupted by the essential change. For example, providing habitat for an endangered bat is unlikely to give direct benefit to a local café owner, even though they may be obliged to change how they light their premises in the evening.

A third problem of citizen control as the best form of public participation is it requires people to have broadly similar levels of health and education (Burden, Fletcher, Herd, Jones, \& Moynihan, 2017). Inequity of health and education are often a symptom of wider structures of oppression (Farmer, 2004). III health demotivates people from thinking in a long time scale as a shorter lifespan prioritises short-term actions (Carstensen, Isaacowitz, \& Charles, 1999). Different relative education levels can cause people to believe in others who they feel are more educated and knowledgeable, thereby giving away their power and devaluing their own thought processes and knowledges leading to coercion (Armingeon \& Schädel, 2015). Conversely, inequitable education can also engen- der a distrust of people who are more educated because of disbelief in their knowledge, leading to aggression and revolt (Cho \& McLeod, 2007).

A fourth problem of presuming that citizen control is the best form of participation is that it does not acknowledge that all these forms of communication and participation can have validity for different circumstances. For example, if infrastructural works have begun, it is unlikely citizens can overturn the decision, therefore informing people of the process and logic by which this decision came about is possibly the best form of participation. Citizens would then understand why and how decisions were made, what rights they have to change things at present, and how they could proceed if faced with similar circumstances in the future.

A fifth participation problem is that each form of communication and participation on the ladder requires citizens to comply with the efforts to change them. Manipulation requires someone to conform. Therapy involves a person to decide and work to alter their thoughts and behaviour. Informing entails the citizen to comprehend new information and incorporate it into their worldview. Consultation involves people to develop and offer their opinions. Placation necessitates citizens to be conciliatory. Partnership obliges people to work with technocrats and elites. Delegated power and control compels citizens to make decisions and take responsibility. For the desired outcome, technocrats, elites and citizens must follow their circumscribed roles, a happenstance that requires particular contexts to occur.

Sixth, if delegated power and citizen control do occur, it is likely that power would shift to particular members of the public to make decisions and take responsibilities, thus replacing one type of technocrat or elite with another, replicating the same power structure that citizen participation aims to mitigate.

A seventh problem with citizen control at the top of the participation hierarchy is it does not acknowledge that people representing institutions, or with particular technical skills, or in command of particular resources, are also citizens and part of the public. By making citizen control the top of the participation hierarchy it implies particular types of people are apart from the public or citizenry. This leads to the question of what and who should be included when considering the public and participation (Andersen, Danholt, Halskov, Hansen, \& Lauritsen, 2015).

Contemporary notions of the public from an actornetwork theory (ANT), socio-technical, or assemblage perspective show how nonhuman actants are part of the public. Without human and nonhuman relationships social relations are not made, knowledge cannot be created, and the idea of the public or participation cannot be enacted (Chilvers \& Kearnes, 2016; Storni, Binder, Linde, \& Stuedahl, 2015). Arnstein's ladder of participation concentrated on the relationship between what she saw as different types of people in society, havenots pitched against elites and technocrats, therefore 
it does not consciously attempt to give voice to nonhuman actants which are also involved in creating publics. Nonhumans include all things except those who identify or are identified as human. These nonhumans form part of the public because they enable, prevent, and circumscribe particular types of interactions between people.

These seven problems need addressing in order to create forms of public participation that enable different types of actants to come together on equal terms to develop ideas of how people may want to live in the world in the future. Five conditions can improve these seven participation problems:

1. Interest and concern;

2. Time commitment;

3. Trust and responsiveness;

4. Knowledge and language differences;

5. Integrating plural perspectives and understandings of benefits and harm for humans and nonhumans.

All five aspects influence each other. For example, if someone is interested or concerned about an issue, then they will be more willing to allocate time to participating in events about it. They are also more likely to spend time learning about the issue thereby increasing their knowledge and vocabulary on the subject. By spending more time and becoming more familiar with the process, trust and expectation of the timing of responses can be built. As trust develops, explorations of knowledge and language differences can occur either through deliberate questioning or by unexpected discovery in conversation. This may then raise new interests and concerns, which gives rise to the integration of plural perspectives, which increases trust and responsiveness, the likelihood of allocating time to the concern, and trust that other participants will be able to represent and take into account viewpoints when individuals are unable to attend all participatory events. Through the process of participation all five aspects need to occur or develop, but to begin an active participatory process the first condition of interest and concern is mandatory. Whilst the five conditions cannot directly address ill health and lack of education, they can respond by creating conditions where people who have ill health or feel lacking in education can participate.

To generate interest and concern amongst citizens is in opposition to most development pursuits. A concerned public adds complexity to the process of bringing projects to fruition by producing a multitude of conflicting concerns and priorities. One way to resolve this initial quandary is to begin the participation process before submission of a project application to a governing body. This solution is concurrent with problem seeking or architectural programming (Duerk, 1993; Faatz, 2009; Peña \& Caudill, 1977). At this point, built environment professionals have not invested much time or money in the project, therefore they are open to incorporating citizen concerns. Citizens do not feel powerless in the face of technical drawings and language, as the project is nascent and undeveloped. This adds a sixth aspect that improves conditions for participation:

6. Begin public participation before any party has invested in a particular outcome.

The idea of games and play in the form of a codesign workshop supports a process of public participation that addresses these six conditions through an intriguing and fun process that allows different views of the future to be explored, expressed, recorded, and included in project proposals.

\section{Codesign Games and CCAT}

Codesign is a term used to cover a spectrum of processes where collective viewpoints achieve a design outcome. The role of the designer is either subsumed as an orchestrator of the process, or dispersed within the collective viewpoint (Binder, Brandt, Ehn, \& Halse, 2015; Storni, 2015). This differs to the most conventional idea of a designer, where they are the arbiter deciding on the spatial and material qualities of things in the world. The rationale for making decisions can stem from the personalyellow is my favourite colour-to the conceptual-when people see this, I want them to experience the warm glow of a tropical sunrise-to the practical-yellow is a colour that is best seen by the human eye in the dark. In each of these instances, the designer imagines the person or people that will interact with their design. Codesign aims to share the task of imagining users and outcomes.

There are different ways to share these imaginings. Product and human-computer-interaction designers have a process of user centred design, where end users are integrated into all stages of the design process from the brief formulation, to testing various iterations of the product, giving feedback to be responded to (Gulliksen et al., 2003). In this process a designer has already decided on the type of thing which they believe they will solve a problem. This process works well for problems that are already tightly bounded ("How do we make a better hairdryer?"). However, it does not work for problems with little or no boundary ("How do we create a sustainable sanitation future?").

Problems that are less circumscribed require a wider set of constituent interactions amongst both humans and nonhumans to both determine problem boundaries and imagine solutions. Codesign games are one process being developed to enable constituents to coalesce, collaborate and create ideas for their future forms of living (Binder et al., 2011; Halse, 2010).

The codesign games developed for the case study used a CCAT framework. This framework takes elements from ANT and socio-technical coevolution. I have previously referred to this framework as coevolutionary ANT (Teh, 2015a), or ANT coevolution (Teh, 2015b). 
CCAT highlights and advances aspects of ANT and socio-technical coevolution. Humans and nonhumans that create the matter of concern are actants. Coevolution refers to the altering of actants relative to one another, whereby the causation of change is mutual rather than one on another. Collective trajectories enables the projection and hypothesis of likely coevolution amongst a given group of actants. Collectives occur when many actants are defined by or are willing to be defined by the same relations. Trajectories are the progression of actant transformations that comes from existing relationships, which limit the type of new relations that can form between actants.

The CCAT framework guided the development of the codesign games and workshop structure. The workshop gathered human participants who were able to articulate relationships between a range of humans and nonhumans. That is, people with different interests in the matter of concern. Enrolment included professionals, technicians, academics, and engaged citizens of different ages and backgrounds. Workshop events enabled people to understand existing human and nonhuman relationships, including visits to places currently affected by the matter of concern, presentation opportunities describing the latter, and an exhibition of the matter of concern. The games played facilitated ways for people to imagine and communicate new human and nonhuman relationships.

The order of workshop events was as important as the events in the workshop. Empirical case studies from socio-technical coevolution reveal that new relations between actants arise from pre-existing relations that alter incrementally over long periods of time, often in response to solving problems that arise from current relations. This means that the events of the workshop needed to progress from understanding existing relations between actants that define the matter of concern before collectively creating new types of network relations between actants. This resulted in the visits, presentations, and exhibitions about the existing situation occurring before games were played.

CCAT also affected the order of the games, which begins with individual thinking before moving to collective imaginings. By starting with individual thinking, participants contribute their concerns to the forum without needing to find consensus. It gave people a chance to ask questions to understand other positions and gave time for trust to develop between participants. By offering each participant a platform to express their concerns, the process began with a sense of respect for all actants involved and brought participants to a common platform of understanding that enabled engagement with the difficult conversations needed in order to find consensus in the later games.

Games in this case refers to structured imaginative play, similar to the games children aged about 1 to 6 freely make up (Fein, 1981; Sutton-Smith, 2001). The games have their own internal logic. All the parts make sense within the game, even if they do not fit in with the current world. They are rehearsals of future scenarios of being an adult. Examples are playing families, schools, hospitals, and battles. Observed and lived experiences as well as imagination are the basis of these scenarios. These types of games allow the players to deepen their understanding of existing and possible future scenarios by playing them out. It is both a learning and creative process.

\section{Codesign Game Workshop for Alternative Sanitation Systems in London}

The two-day workshop was titled "New Loos for London?" It brought together fourteen participants with one facilitator to the University College London Bloomsbury campus to play codesign games that explored sanitation futures for London.

The fourteen participants represented various concerns about sanitation: three developers of alternative sanitation systems that were on the market; one distributor of alternative sanitation systems in London; one owner of a company that produces alternative sanitation systems; three interested citizens; an environmental policy consultant; a solid waste policy maker; a wastewater and sludge industry based researcher; a socio-environmental engineering academic; a history of design academic; and a sustainable urban design academic. Workshop participants were not asked about their level of education, gender, or ethnicity. The observable characteristics were that most people appeared to have at least university-level education, though one or two participants may not. Four participants were women, nine participants were men, and the facilitator was a woman. English was not the first language of one participant, and one participant was non-Caucasian. The mix of participants is an outcome of their various concerns about sanitation and their ability to volunteer their time rather than a representative mix of ethnicities, education levels, and genders in society.

The workshop organiser identified and personally invited participants professionally involved with aspects of sanitation and waste, with additional invitations extended when invitees made suggestions. Citizens were invited through an online forum Project Dirt (now Semble) that allows members to invite others to sustainability events they are organising. Membership is free and wide varieties of people are members. Attendees who lived out of London were reimbursed for one night of accommodation and rail fares. The timing of the workshop coincided with a business trip for an overseas participant to attend.

All participants were requested to commit to the whole two-day workshop, however three people had to leave early. One person participated for the first day; another left after the first game and another after the first hour of the third game on the second day.

The first day of the workshop was for humans and nonhumans to begin knowing other's existing network 
relations, concerns, and to develop trust amongst participants. The second day was for humans to explore new types of network relations between nonhuman and human actants.

Day one of the workshop began at 9:00 AM with an introductory exercise to create a photo wall displaying photographs brought by each participant of their home toilet by way of introducing themselves (Figure 1). This established the ubiquity of the flush toilet connected to a sewer system amongst participants. Only one participant had an alternative form of sanitation-a vacuum flush compost toilet. Tea, coffee and breakfast pastries were available during the introductions. A photo printer was also available, so all participants had the ability to have digital photos printed.

Following the introduction, all participants boarded a minibus to go to the North London Ecopark, a solid waste processing centre based in Tottenham. The Ecopark treats solid organic waste for compost, sorts and packages recyclables, sends some waste to landfill, and incinerates remaining waste for electricity and heat. It is a collaborative project by seven boroughs in London, which handles about 583,000 tonnes of waste per year (North London Waste Authority, 2018). Following the tour, lunch was provided, and the group continued to Deephams Wastewater Treatment Works, which was conveniently located next door. Thames Water runs Deephams which treats $209,000 \mathrm{~m}^{3}$ of wastewater on an average day, which is approximately 885,000 people's daily wastewater (Robbins, 2015; Water Technology, ca. 2015). All participants were impressed by both the solid waste and waste water treatment plants for their size, sophistication, organisation, and the care they took to protect the environment from pollutants.

After viewing the large plants handling waste, the tour continued to visit a typical residential area of London whose solid and liquid waste is treated at the Ecopark and Deephams. On return to the UCL campus, a small exhibition was held with physical examples of three types of alternative sanitation systems that were developed or sold by participants (Figure 2). Systems included a packaging system, a tiger worm treatment system, and a desiccating compost system. The four developers and distributors of alternative sanitation systems also gave presentations, and answered questions about their systems, which concluded the first day of the workshop at about 7:30 PM. Drinks and snacks were available during the exhibition and presentations.

The second day began with creating another photo wall and review about what people found most interesting from the previous day's site visits. Participants then played three codesign games, developed specifically for the workshop (Table 1). The first game begins with individual thinking, the second concentrates on system interaction and the third collaborative decision making. After the first two games, participants had a one and a half hour lunch break at a nearby restaurant. The last game took three hours. A short film screening of the results from the last game, followed by discussion and feedback concluded the workshop. A few days after the workshop, participants were emailed a thank you note and feedback questions.

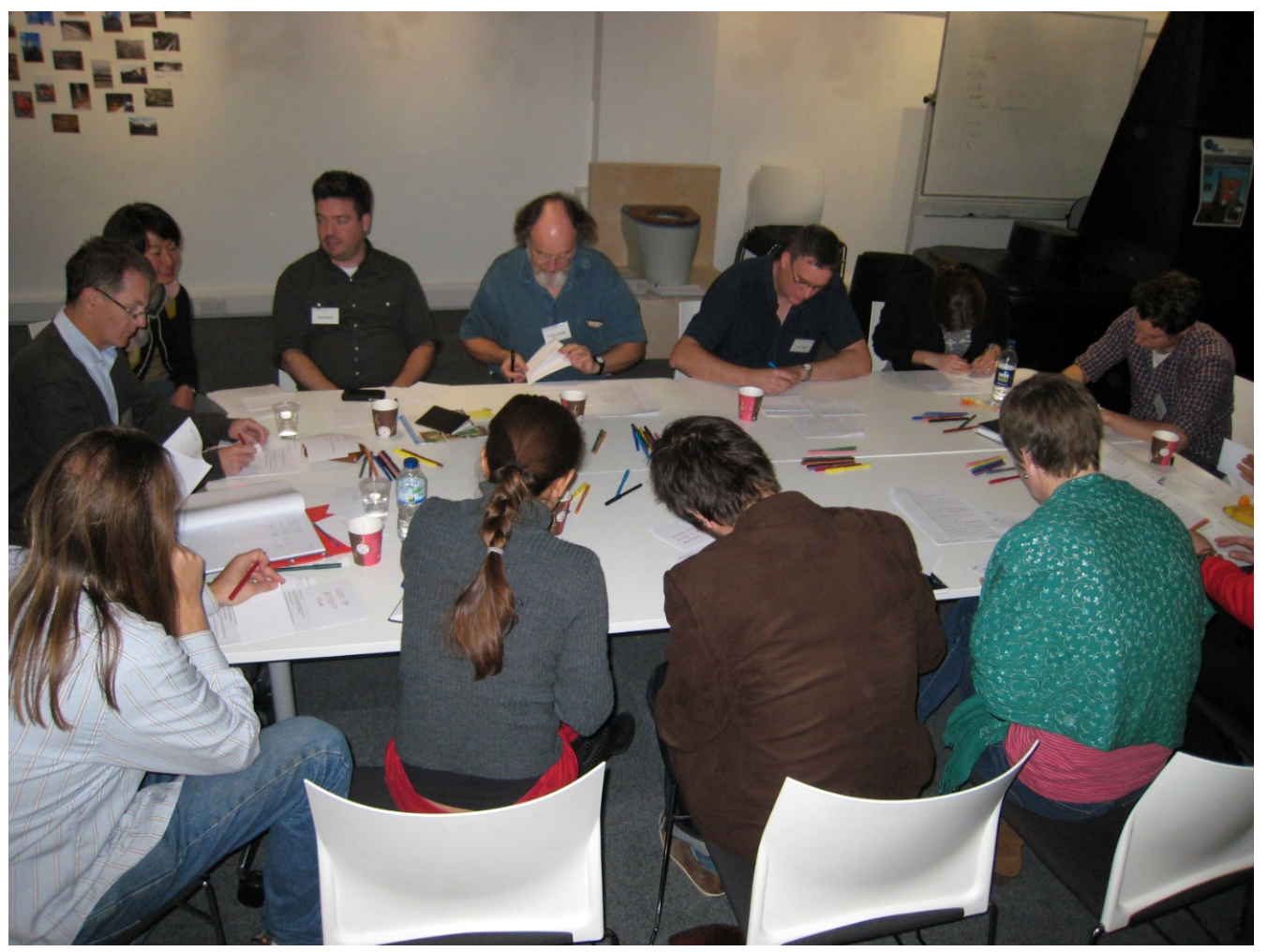

Figure 1. Participants playing Macromoves. Introductory photo wall in the background. Photograph by Danielle Willkens. 


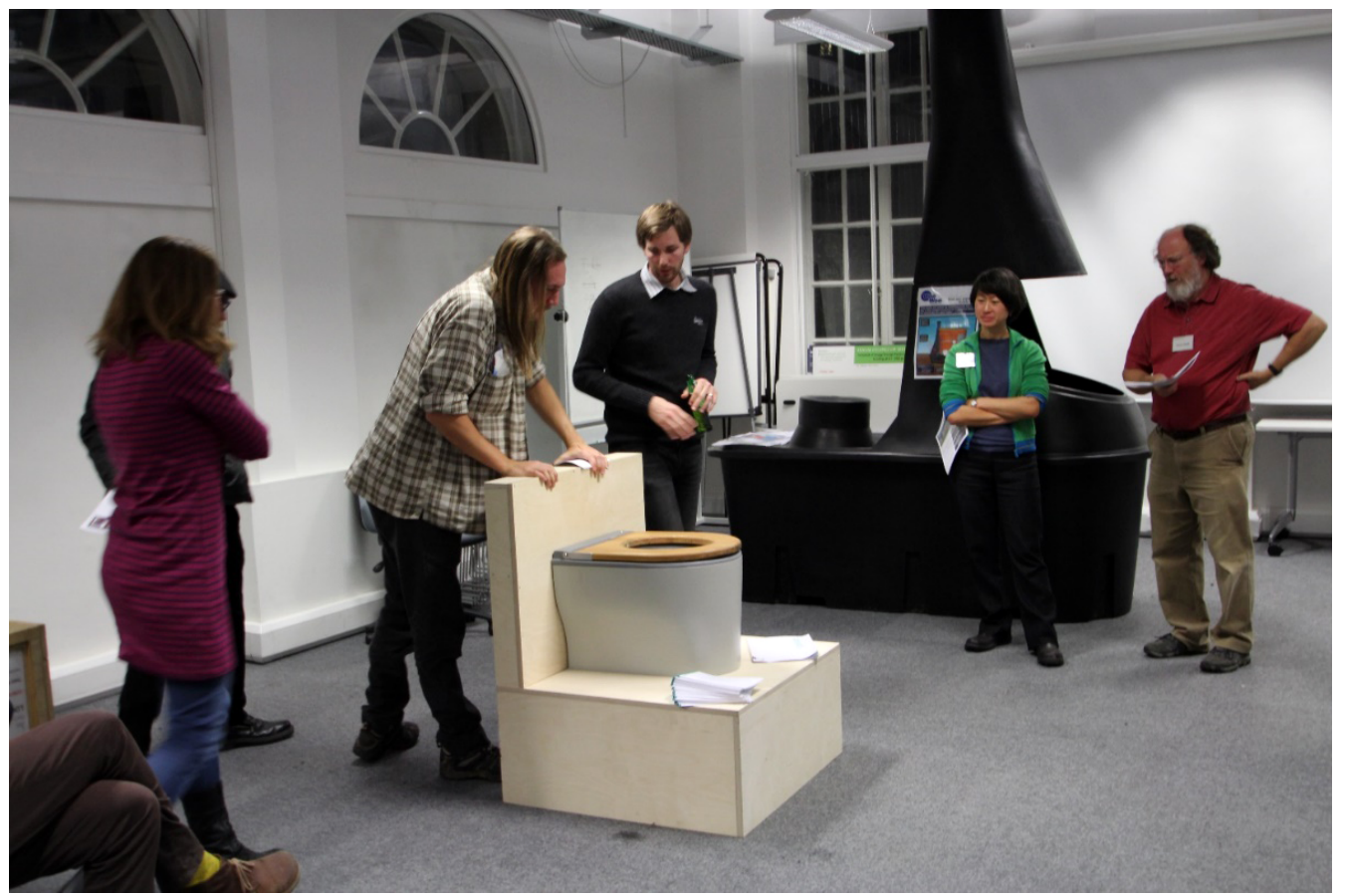

Figure 2. Alternative sanitation exhibition. Photograph by Danielle Willkens.

Table 1. Synopsis of games in sequence of play.

\begin{tabular}{|c|c|c|c|}
\hline Name of Game & Aim & Types of actions & Outcome \\
\hline Macromoves & $\begin{array}{l}\text { Discovering what individuals and } \\
\text { the group think would prevent or } \\
\text { promote change }\end{array}$ & $\begin{array}{l}\text { Individual thinking, followed by } \\
\text { large group analysis, then small } \\
\text { group play }\end{array}$ & Story based scenarios \\
\hline I-Count & $\begin{array}{l}\text { Exploring influences in relations } \\
\text { between actants in a system }\end{array}$ & $\begin{array}{l}\text { Individual decisions, within } \\
\text { large group play }\end{array}$ & $\begin{array}{l}\text { Alternative sanitation } \\
\text { systems }\end{array}$ \\
\hline Landed & $\begin{array}{l}\text { Create a system, with its } \\
\text { own context }\end{array}$ & Small group play & $\begin{array}{l}\text { Video describing a scenario and } \\
\text { the alternative sanitation } \\
\text { system it supports }\end{array}$ \\
\hline
\end{tabular}

The first game, Macromoves, began with individual points of view about what types of concerns would help or hinder the implementation of an alternative sanitation system in London. Each concern was written on one index card, after each participant had written as many ideas as they had, the group then came together to read aloud their ideas and collate them thematically. The thematic analysis allowed people to see what ideas had the most strength by the number of people who had similar ideas. The index cards were then turned over and shuffled. Each person took six cards and formed groups of 3 to 4 people to re-examine the cards that they had collectively gathered. Based on these cards, each group created contexts for future sanitation systems. The shuffling and reallocation of the cards is to imitate life, where the future is made of some ideas which can be anticipated today, but which ideas emerge as influential can also be unexpected. These groups developed four scenarios: "Brown Economy," "Wonderloo," "Yes to Dry," and "Cost." These scenarios of the larger context in which alternative sanitation may or may not occur formed part of the background for the final game Landed.

The second game, I-Count, was played as one large group of 12 people. Each person received a random card representing a part of a sanitation system. For example, the toilet, the receiving environment, the treatment system, the conveyance for waste, the person using the toilet, pollution, cost, and so on. A dice was then rolled until a participant rolled a 1 . When they did so, they then made a decision about how their role in the system would play out. How it could play out was dependent on all preceding decisions from other players. In other words, the first person to roll 1 was able to exert the most influence, because all subsequent decisions had to accommodate all preceding decisions. Each participant provided a written and drawn description of their decision and placed it in the consecutive order of decisions made. Some participants spontaneously let the group know what part of the system they represented and asked for advice from the group before making their 
decision. Other participants stated their decision without input from the group. These contrasting ways of playing reflected people's personal preferences and styles of interaction. Each had its own advantages in the way it opened up discussions about relations between actants. Participants were respectful that each person had their turn to make a decision for their part of the system. This was because each participant wanted the chance to make their own decision without pressure from others, most participants did not have any preceding social ties with other participants, and everyone wanted to find out the consequences of the decisions made to the sanitation system it created.

To show how different parts of the system inhibited or gave opportunities for particular types of relationships the game was played twice. The two systems were different but made sense within themselves. The contrast gave evidence and experience of how actants related to each other to the participants. Participants could have played the game more than twice to increase depth of system knowledge, but there was insufficient time to do so within this workshop.

On completion of the two systems, participants analysed the parts that they liked, and those that they did not. Those that they liked were noted on green sticky notes; and those that were disliked on red sticky notes. Areas that were most liked and disliked were noted as things to include or avoid for the third game Landed. Relationships for participants to include were: reduction of pollution; efficient resource recovery; and selfsustainability. Relationships to avoid were: high energy costs; noisy function; easy vandalism; high initial implementation cost; and manual carting of waste.
Landed was the final synthesis game. Participants were given three hours in which to create a short 4-minute video about future sanitation systems in London. Participants worked in self-selected groups of 3 to 4 people. They were given various materials to make the video, such as cardboard, paper, sticky tape, glue, blu-tak, photographs, modelling clay, and Lego figures as characters in the scenario. Participants were also free to add whatever objects and materials they thought necessary to create their scenario. Each future sanitation system was in response to the site visits completed on day one, a scenario from Macromoves selected by a dice roll, and the I-Count elements to include and avoid.

\section{Codesigned Alternative Sanitation Possibilities in London}

Landed resulted in three scenarios: "Silvia Does a Poo," "McWorm," and "Status Quo." "Silvia Does a Poo" had the scenario "Yes to Dry." The people creating the video were one developer and one owner of a company that produces alternative sanitation systems, one socio-environmental engineering academic, and a history of design academic. The video describes what happens when Silvia does a poo, and when she does a pee in a public toilet (Figure 3). When Silvia does a poo, it is conveyed via a retrofitted vacuum flush system in the existing sewers of London. These pipes lead to a local biodigestor that also treats local food waste. The biogas from this process generates electricity to run the vacuum system, heat for a communal heating network, with any additional energy used for street lighting. The compost from the system is distributed to farmers as a fertilizer.

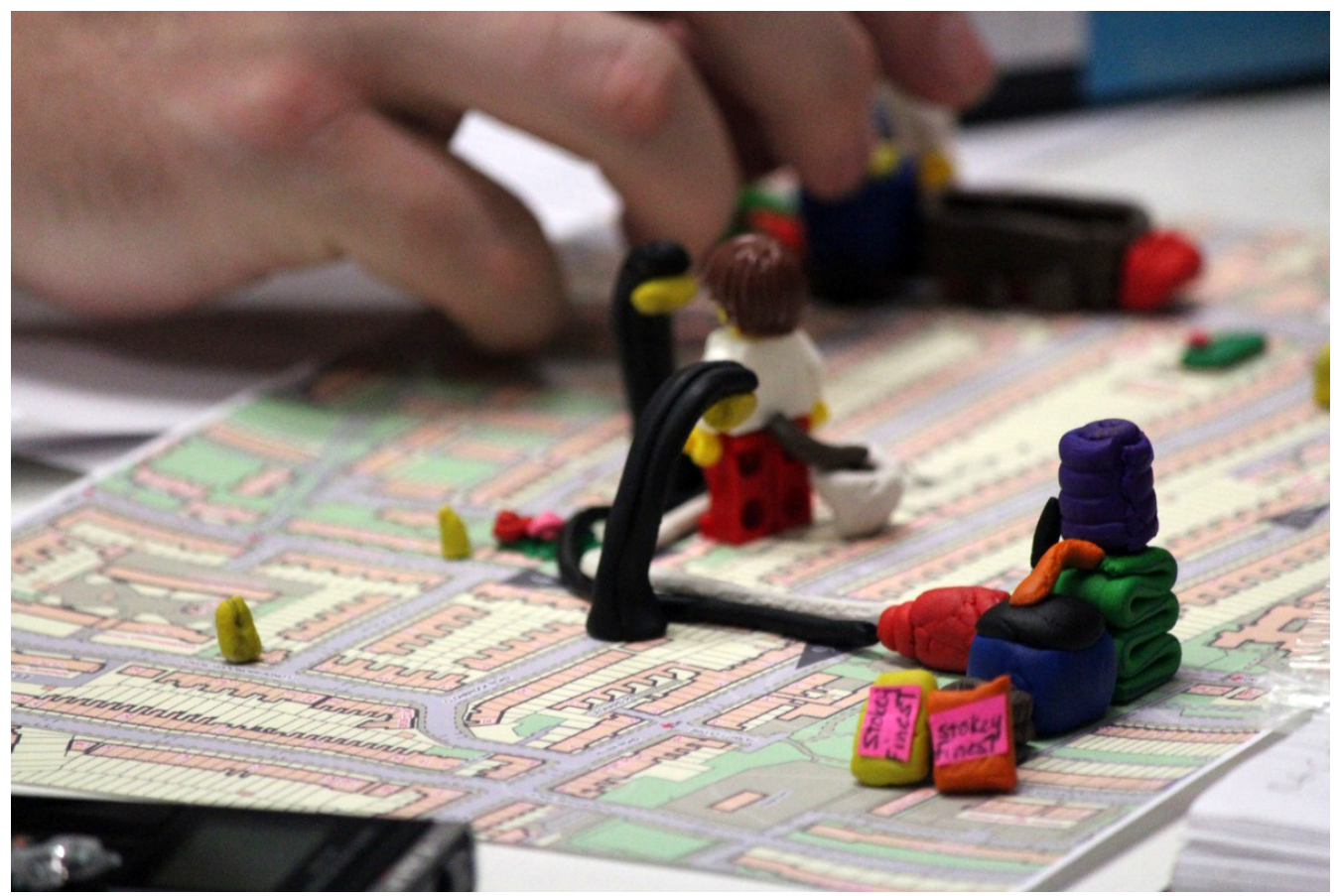

Figure 3. "Silvia Does a Poo" scenario. Photograph by Danielle Willkens. 
When Silvia does a pee at the local pub, it is collected as a fertilizer for farmers. During the weekend, local farmers from Essex sell produce at the neighbourhood farmers' market to Silvia and her neighbours. Before the farmers leave, they collect the urine and compost to fertilize the crops they will sell in the market. Neighbourhood gardens benefit from any extra compost produced. In the contemporary city of London, "Silvia Does a Poo" imagines how the nutrient cycle is closed.

"McWorm" also had the "Yes to Dry" scenario. The participants creating this video were two interested citizens, an environmental policy consultant, and a wastewater and sludge industry based researcher. "McWorm" is a tale where a neighbourhood band together to increase their resilience to sewer problems and food by collaborating with a developer to retrofit a vacuum toilet system in the neighbourhood (Figure 4). The funds for this collaboration come from selling the rights to a McWorm burger which is made from worm protein from the sanitation system. New vacuum toilets are retrofit in the neighbourhood, the vacuum system runs inside the existing sewer system, which connect to an anaerobic digester, then to a composting area that feeds worms and creates clean compost. Neighbourhood gardeners receive compost, and worms are turned into burgers. People can eat their own produce and the worm burgers to metabolise into more worm food. "McWorm" also closes the nutrient cycle but is more futuristic than "Silvia Does a Poo" because it imagines the use of a protein source not widely used in contemporary London.

"Status Quo" had the scenario "Cost." The makers of the video were an interested citizen, a solid waste policy maker, and a sustainable urban design academic.
This group also had the contributions of a distributor of alternative sanitation systems at start of the game, but this participant left before the filming of the final video. "Status Quo" described a public meeting held about the possibility of implementing a new sanitation system which involved storing waste in containers in the basement of buildings, which were then collected by electric vehicle, and transported to an anaerobic digestor for treatment and resource harvesting including electricity to power the collection vehicle (Figure 5). The anaerobic digestor was located in a local playground. Two people then report their impressions about the discussion. One enthusiastic community member talks to their partner over the kitchen sink. The partner raises many objections including traffic congestion, contamination from transporting waste through the streets, malodour, gas explosions, no necessity to make this change because water is cheap, and the lack of improvement to the current system that already generates electricity and fertilizer. They were also unsupportive because it would mean changing the recently renovated bathroom. The other reporter was an observer from the local water and sewage provider to their boss, who stated that their business was safe because the community had raised too many objections about the implementation of a new sanitation system.

The three videos demonstrate diverse ways in which collectives of actants coevolve relations in trajectories from relationships that exist today. The two groups who envisaged the implementation of a resource harvesting sanitation system by retrofitting the existing sewer system with vacuum flush pipes both had the scenario "Yes to Dry." However, the resources harvested, the organi-



Figure 4. "McWorm" scenario. Photograph by Danielle Willkens. 


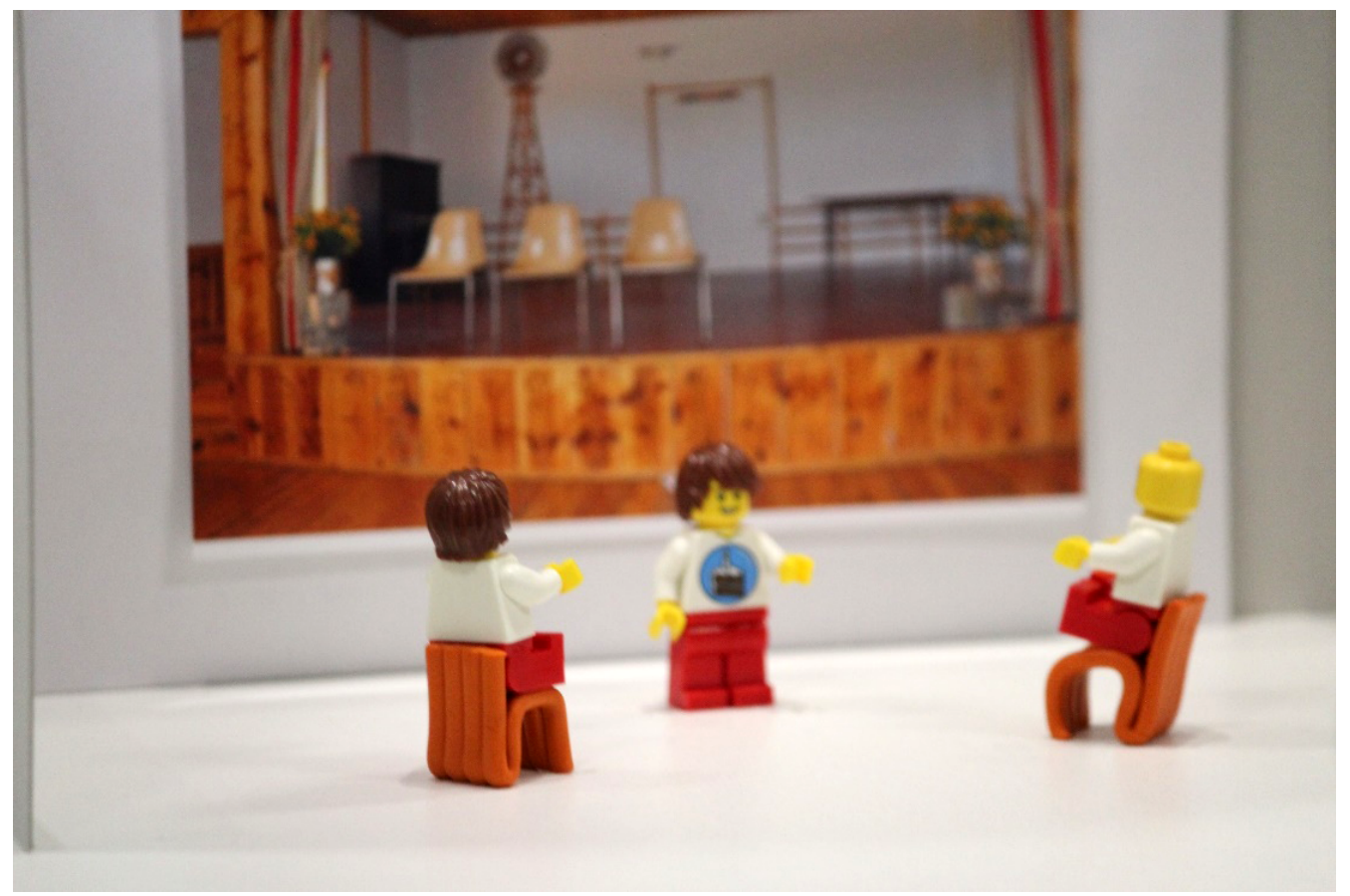

Figure 5. "Status Quo" scenario. Photograph by Danielle Willkens.

sation of the harvesting, and the financing of the implementation and operation were not alike. "McWorm" develops on existing cultures of fast food consumption and their transformation of food supply chains. Research for alternative protein sources have been sought for many years in the face of population growth, land and animal rights pressures. Worms form part of traditional diets the world over so it is conceivable as a future protein source (Martin, 2014). It also envisages benefits for local gardens through the distribution of compost that is another product from the sanitation system. "Silvia Does a Poo" contrasts this with fertilizer resources distributed to local farmers and gardeners, district heating, and electricity to power the vacuum system and street lighting. It builds on an existing culture of local farmers markets in London, supplying them with a source of fertilizer that is novel today, but commonly used in the past. "Status Quo" received "Cost" as the scenario within which to develop their sanitation system video. For this group, public safety, personal change, and the need to maintain the profitability of the privatised wastewater provider in London prohibited an alternative sanitation system.

Each imagined future plays with the collective entanglements between human and nonhuman actants. Their trajectories reside in today's relations but coevolve for a tomorrow where new collaborations abound. These coevolved relationships between humans and nonhumans were not described in a reductive or singular way. Instead, they articulated the multiple benefits and detriments that each sanitation systems' alliances created, allowing people to make decisions about the types of compromises they were willing to make for the corresponding advantages.

\section{Improving the Process of Participation with the Codesign Game Workshop}

The formulation of the "New Loos for London?" codesign game workshop addressed the six conditions identified to improve participation. Most importantly, the public participation workshop was held well in advance of any party investing in a particular outcome. The topic was of interest and concern to the organisers of the workshop, the wider human population in London and globally, and water dependent ecological systems. The organisers had no stake in a solution. The facilitator did not help play the codesign games or encourage specific discussion points, confirming the organisers' lack of advocacy for a specific outcome from the workshop. The only intention was to allow participants to generate possibilities that would identify ways in which humans and nonhumans could coevolve for alternative sanitation systems to occur in London's future.

The two-day time commitment for this workshop was both an advantage and an impediment for participation. The restriction created a group of participants who were engaged in the workshop process because they had committed and sometimes justified to their employers the two days from their working week for the workshop. Three of the fourteen workshop attendees did need to leave early, but all stayed longer than planned, showing how the workshop process engenders more interest and concern resulting in people committing more time to the process.

Participating in the workshop did not require specialist skills or knowledge. The things used to communicate ideas were familiar. The workshop introduced new con- 
cepts and experiences to each participant, so everyone felt that they were learning as well as contributing ideas.

The most significant advantage to the two-day workshop was enabling points three and four: trust and responsiveness; and knowledge and language differences. Despite all participants being engaged, there were many instances where people spent time clarifying vocabulary, ideas, viewpoints, and ways of knowing in order to assimilate and critique new knowledges or alter existing ones. There were no circumscribed roles of technocrats and elites versus citizens because people firstly met as people with a common concern, and then as people with different types of knowledge which had bearing on the concern.

The relationships between nonhuman and human actants were central throughout this process. The icebreaker included pictures of homes and toilets, demonstrating similarities or differences in daily life, norms, and expectations formed by relationships with particular nonhumans. The tour viewed and discussed the functions, spaces, organisation, technologies and limitations of solid and liquid waste treatment works. The exhibition showed new nonhumans which are not a part of current systems but may have roles to play in future systems. Nonhumans sometimes demonstrated their requirements by being present, but frequently a human explained their less apparent qualities. For instance, the type of environment microbes treating liquid waste require to clean water of pathogenic contents; and in the second game, l-Count where people role played the nonhuman parts of the sanitation system. The final game, Landed, demonstrated possible future relations between humans and nonhumans derived from these shifting perspectives of actants and demonstrated an integration of plural perspectives.

\section{Conclusion}

The practicalities of undertaking public participation events which sincerely include and balance concerns from citizens and built environment professionals challenges the widely held belief in public participation as best practice. The often-used Arnstein's ladder of participation sets a frame of public participation of elites and technocrats against other citizens; and excludes nonhumans that form part of the concerned public. From this critique, six aspects emerged that would enable a public participation process which is more inclusive of and responsive to the differing needs of publics: The process should start before a group of people have invested so much in its development that they are unwilling to alter their project; participants need to have an interest and concern about the project; they need to have time to participate; the process needs to develop trust and responsiveness to differing viewpoints; allow for knowledge and language differences to be explored; and be able to integrate plural perspectives and understandings of benefits and harm for humans and nonhumans. The six aspects are interrelated, reinforcing or undermining each other, should an aspect occur or not.

The two-day workshop developed using a CCAT framework created and conducted a public participation event demonstrating a process integrating the six conditions. The workshop occurred before any participants had a stake in a particular outcome. It brought together people who were interested and concerned about the sanitation system and built on this through the workshop. All participants gave as much time as they were able. Knowledge and language differences were given time to resolve into common understandings through the full day of visiting examples, and within the codesign games on the second day. Plural perspectives of benefits and harm for humans and nonhumans were expressed throughout the playing of all three codesign games because of their structure but were most clearly articulated in the last game Landed.

The final synthetic game Landed showed that public participation need not be a hierarchical, adversarial, box-ticking exercise, dividing technocrats and elites from all other citizens. The codesign process revealed the relationships between actants, and gave multiple perspectives validity, contingency, and fluidity. This understanding allowed the exploration of new relationships for mutually beneficial scenarios and compromises. Arnstein's ladder was redundant because participants did not divide themselves into technocrats, elites and have-nots. Instead, they were people with a common concern, with unique viewpoints and knowledge to contribute to the discussion. These are valuable experiences and knowledge for participants to carry forward. In this case, the outcomes demonstrated two possibilities for future sustainable sanitation systems in London, and a prospect of stymying alternative systems. These imaginings contribute to transforming London's unsustainable reliance on the flushing toilet to a sustainable system. Future research could test the ability and limits of codesign games to continue engaging and encouraging publics to deliberate and act for collective benefits.

\section{Acknowledgments}

Thanks go to Dr Danielle Willkens as the research assistant and workshop facilitator, Professor Barbara Penner for her support as research coinvestigator, Dr Joachim Halse, Prof Thomas Binder and members of the Centre for Codesign Resarch, Royal Danish Academy of Fine Arts, for feedback during the development of the codesign games. Thanks are also due to the University College London "Grand Challenges, Sustainable Cities" for workshop funding, and the anonymous reviewers for their encouragement and feedback on the article.

\section{Conflict of Interests}

The author declares no conflict of interests. 


\section{References}

Andersen, L. B., Danholt, P., Halskov, K., Hansen, N. B., \& Lauritsen, P. (2015). Participation as a matter of concern in participatory design. CoDesign, 11(3/4), 250-261.

Armingeon, K., \& Schädel, L. (2015). Social inequality in political participation: The dark sides of individualisation. West European Politics, 38(1), 1-27.

Arnstein, S. R. (1969). A ladder of citizen participation. Journal of the American Institute of Planners, 35(4), 216-224.

Ballon, H., \& Jackson, K. T. (Eds.). (2007). Robert Moses and the modern city: The transformation of New York. New York, NY: W.W. Norton and Company.

Beebeejaun, Y. (Ed.). (2016). The participatory city. Berlin: Jovis.

Binder, T., Brandt, E., Ehn, P., \& Halse, J. (2015). Democratic design experiments: Between parliament and laboratory. CoDesign, 11(3/4), 152-165.

Binder, T., Ehn, P., Michelis, G. D., Jacucci, G., \& Linde, G. (2011). Design things. Cambridge, MA: MIT Press.

Brandt, E., Messeter, J., \& Binder, T. (2008). Formatting design dialogues: Games and participation. CoDesign, 4(1), 51-64.

Brlík, M., \& Pelčíková, P. (2018). Participation handbook: Executive summary. Prague: Prague Institute of Planning and Development.

Brownill, S., \& Inch, A. (2019). Framing people and planning: 50 years of debate. Built Environment, 45(1), 7-25.

Burden, B. C., Fletcher, J. M., Herd, P., Jones, B. M., \& Moynihan, D. P. (2017). How different forms of health matter to political participation. The Journal of Politics, 79(1), 166-178.

Caro, R. (2015). The power broker: Robert Moses and the fall of New York. London: The Bodley Head.

Carstensen, L. L., Isaacowitz, D. M., \& Charles, S. T. (1999). Taking time seriously: A theory of socioemotional selectivity. American Psychologist, 54(3), 165-181.

Chilvers, J., \& Kearnes, M. (2016). Remaking participation: Science, environment and emergent publics. New York, NY: Routledge.

Cho, J., \& McLeod, D. M. (2007). Structural antecedents to knowledge and participation: Extending the knowledge gap concept to participation. Journal of Communication, 57(2), 205-228.

Department of Economic and Social Affairs of the United Nations Secretariat. (2007). Participatory dialogue: Towards a stable, safe and just society for all (Report No. ST/ESA/310). New York, NY: United Nations.

Drazkiewicz, A., Challies, E., \& Newig, J. (2015). Public participation and local environmental planning: Testing factors influencing decision quality and implementation in four case studies from Germany. Land Use Policy, 46, 211-222.

Duerk, D. (1993). Architectural programming: Information management for design. New York, NY: John Wi- ley and Sons.

European Council of Spatial Planners. (2016). European charter on participatory democracy in spatial planning processes. Brussels: European Council of Spatial Planners.

Faatz, S. (2009). Architectural programming: Providing essential knowledge of project participant needs in the pre-design phase. Organization, Technology and Management in Construction, 1(2), 80-85.

Farmer, P. (2004). Pathologies of power: Health, human rights, and the new war on the poor. Berkeley, CA: University of California Press.

Fein, G. G. (1981). Pretend play in childhood: An integrative review. Child Development, 52(4), 1095-1118.

Flores, A. (2005). Local democracy in modern Mexico: A study in participatory methods. Bury St. Edmonds: Arena Books.

Gulliksen, J., Göransson, B., Boivie, I., Blomkvist, S., Persson, J., \& Cajander, А. (2003). Key principles for usercentred systems design. Behaviour \& Information Technology, 22(6), 397-409.

Halse, J. (2010). Rehearsing the future. Copenhagen: Danish Design School Press.

Hendrix, B. A. (2007). Moral error, power and insult. Political Theory, 35(5), 550-573.

Intergovernmental Panel on Climate Change. (2018). Global Warming of $1.5^{\circ} \mathrm{C}$ : Summary for policymakers. (Special Report). Geneva: Intergovernmental Panel on Climate Change. Retrieved from https://www. ipcc.ch/sr15

Jacobs, J. (1961). The death and life of great American cities. New York, NY: Vintage Books.

Lauwaert, M. (2009). Playing the city: Public participation in a contested suburban area. Journal of Urban Technology, 16(2), 143-168.

Le Corbusier. (1947). The city of to-morrow and its planning. London: Architectural Press. vLowndes, V., Pratchett, L., \& Stoker, G. (2001). Trends in public participation: Part 2-Citizens' perspectives. Public Administration, 79(2), 445-455.

Martin, D. (2014). Edible: An adventure into the world of eating insects and the last great hope to save the planet. New York, NY: New Harvest Houghton Mifflin Harcourt.

Ministry of Housing Communities and Local Government (2019). National planning policy framework. London: Ministry of Housing Communities and Local Government.

North London Waste Authority. (2018). Annual report 2017-2018. London: North London Waste Authority.

NSW Government. (2018). Community participation plan: The department of planning and environment exhibition draft October 2018. Sydney: Department of Planning and Environment. Retrieved from https:// www.planning.nsw.gov.au/-/media/Files/DPE/Plansand-policies/community-participation-plan-draft2018-10.PDF

Peña, W., \& Caudill, W. W. (1977). Problem seeking: An 
architectural programming primer. Boston, MA: Cahners Books International.

Robbins, A. (2015). Deephams sewerage treatment works. Manchester: WaterProjectsOnline. Retrieved from https://waterprojectsonline.com/wp-content/ uploads/case_studies/2015/Deephams-STW2015.pdf

Royal Institute of British Architects. (2019). Pathways to qualify as an architect. Royal Institute of British Architects. Retrieved from https://www.architecture. com/education-cpd-and-careers/how-to-becomean-architect

Royal Town Planning Institute. (2019). Assessment of professional competence. Royal Town Planning Institute. Retrieved from https://www.rtpi.org.uk/ membership/assessment-of-professionalcompetence

Rumore, D., Schenk, T., \& Susskind, L. (2016). Role-play simulations for climate change adaptation education and engagement. Nature Climate Change, 6(8), 745-750.

Schütz, F., Heidingsfelder, M. L., \& Schraudner, M. (2019). Co-shaping the future in quadruple helix innovation systems: Uncovering public preferences toward participatory research and innovation. She Ji: The Journal of Design, Economics, and Innovation, 5(2), 128-146.

Sedlitzky, R., \& Franz, Y. (2019). "What if we all chip in?" Civic crowdfunding as alternative financing for urban development projects. Built Environment, 45(1), 26-44.
Slotterback, C. S., \& Lauria, M. (2019). Building a foundation for public engagement in planning. Journal of the American Planning Association, 85(3), 183-187.

Smithson, A. (1967). Urban structuring: Studies of Alison \& Peter Smithson. London: Studio Vista.

Storni, C. (2015). Notes on ANT for designers: Ontological, methodological and epistemological turn in collaborative design. CoDesign, 11(3/4), 166-178.

Storni, C., Binder, T., Linde, P., \& Stuedahl, D. (2015). Designing things together: Intersections of co-design and actor-network theory. CoDesign, 11(3/4), 149-151.

Subašić, E., Reynolds, K. J., \& Turner, J. C. (2008). The political solidarity model of social change: Dynamics of self-categorization in intergroup power relations. Personality and Social Psychology Review, 12(4), 330-352.

Sutton-Smith, B. (2001). The ambiguity of play. Cambridge, MA: Harvard University Press.

Teh, T.-H. (2015a). Coevolving water sustainability in London. ACME: An International Journal for Critical Geographies, 14(3), 721-734.

Teh, T.-H. (2015b). Bypassing the flush, creating new resources: Analysing alternative sanitation futures in London. Local Environment, 20(3), 335-349.

Water Technology. (ca. 2015). Deephams sewage treatment works, Edmonton. Water Technology. Retrieved from https://www.water-technology.net/ projects/deephams-sewage-treatment-worksedmonton

\section{About the Author}



Tse-Hui Teh (PhD) is a Lecturer of Urban Design and Planning at the Bartlett School of Planning, University College London. She uses a collective coevolution of actant trajectories (CCAT) framework to understand how water and sanitation infrastructures can become sustainable. She also uses CCAT to create codesign games that enable public participation to change urban infrastructure. Her current projects look at urban rice and cress farming in Antananarivo, water reuse in Sydney, and vacuum flush toilets in London. 